\title{
Stage IB Soft Tissue Sarcoma AJCC v7
}

National Cancer Institute

\section{Source}

National Cancer Institute. Stage IB Soft Tissue Sarcoma A/CC V7. NCI Thesaurus. Code C8580

Stage IB includes: (T2a, N0, M0, G1, GX); (T2b, N0, M0, G1, GX). T2a: Superficial tumor more than $5 \mathrm{~cm}$ in greatest dimension. T2b: Deep tumor more than $5 \mathrm{~cm}$ in greatest dimension. N0: No regional lymph node metastasis. M0: No distant metastasis. G1: Grade 1. GX: Grade cannot be assessed. (AJCC 7th ed.) 